\title{
Energy auditing of chemical industry and scope for renewable energy
}

\author{
A.U. SANAP, SURENDRA KOTHARI, N.L. PANWAR AND VINOD YADAV
}

\begin{abstract}
Chemical industry is one of the oldest industries in India. Indian chemical sector has grown a long way since its early days of independence. The chemical industry forms the backbone of the industrial and agricultural development in India and also provides building blocks for downstream industries. This industry is a significant contributor to India's national economic growth. To know the extent of energy being wasted it is essential to know the amount of energy being consumed. Energy audit is an inspection, survey and analysis of energy flows for energy conservation to reduce the amount of energy input into the system without negatively affecting the output. The energy audit is the key for decision-making in the area of energy management. This paper presents, electrical energy auditing carried out in production plant of (PIL) chemical industry, in which lighting system was tested according to BEE standards. The annual energy wastage through lighting system was $528.24 \mathrm{kWh}$ and found $600 \mathrm{kWh}$ annual energy saving opportunities by replacing high power rating lamps. It was suggested that $2 \mathrm{~kW}$ capacity solar photovoltaic (SPV) system is capable for running indoor lighting system. Payback period of the SPV system comes 44 months compare to conventional electricity.
\end{abstract}

KEY WORDS : Energy audit, Chemical Industry, Renewable energy, Lighting system

How to cite this Article : Sanap, A.U, Kothari, Surendra, Panwar, N.L. and Yadav, Vinod (2014). Energy auditing of chemical industry and scope for renewable energy. Engg. \& Tech. in India, 5 (1\&2) : 80-86. 